PART I: STI PRODUCT DESCRIPTION

(To be completed by Recipient/Contractor

A. STI Product Identifiers

1. REPORT/PRODUCT NUMBER(s)

NONE

2. DOE AWARD/CONTRACT NUMBER(s)

DE-FG 36-02 GO 12033

3. OTHER IDENTIFYING NUMBER(s)

NONE

B. Recipient/Contractor

Technological Research and Development Authority

C. STI Product Title

Final Report DE-GH 36-02 GO 12033

D. Author(s)

Kershaw, David

E-mail Address(es):

DKershaw@TRDA.ORG

E. STI Product Issue Date/Date of Publication

$12 / 10 / 2003$ $(\mathrm{mm} / \mathrm{dd} / \mathrm{yyyy})$

F. STI Product Type (Select only one)

1. TECHNICAL REPORT

x Final $\square$ Other (specify)

2. CONFERENCE PAPER/PROCEEDINGS

Conference Information (title, location, dates)

\section{JOURNAL ARTICLE}
a. TYPE: $\square$ Announcement Citation Only $\square$ Preprint $\square$ Postprint

b. JOURNAL NAME

c. VOLUME

d. ISSUE

e. SERIAL IDENTIFIER (e.g. ISSN or CODEN)

\section{OTHER, SPECIFY}

G. STI Product Reporting Period ( $\mathrm{mm} / \mathrm{dd} / \mathrm{yyyy}$ )

$09 / 15 / 2002$

Thru

$09 / 14 / 2003$
H. Sponsoring DOE Program Office

Golden Field Office

I. Subject Categories (list primary one first)

Business Development

Keywords

J. Description/Abstract

See Attachment

K. Intellectual Property/Distribution Limitations

(must select at least one; if uncertain contact your Contracting Officer (CO))

$x$ 1. UNLIMITED ANNOUNCEMENT (available to U.S. and non-U.S. public; the Government assumes no liability for disclosure of such data)

2. COPYRIGHTED MATERIAL: Are there any restrictions based on copyright? $\square$ Yes $\square$ No If yes, list the restrictions as retained in your contract

3. PATENTABLE MATERIAL: THERE IS PATENTABLE MATERIAL IN THE DOCUMENT INVENTION DISLOSURE SUBMITTED TO DOE: DOE Docket Number: S-

(Sections are marked as restricted distribution pursuant to 35 USC 205)

4. PROTECTED DATA: $\square$ CRADA $\square$ Other If other, specify

Release date $(\mathrm{mm} / \mathrm{dd} / \mathrm{yyyy})$

5. SMALL BUSINESS INNOVATION RESEARCH (SBIR) DATA

Release date (Required, (No more than 4 years from date listed in part 1.E above)

6. SMALL BUSINESS TRANSFER (STTR) DATA

Release date (Required, No more than 4 years from date listed in part 1.E above)

7. OFFICE OF NUCLEAR ENERGY APPLIED TECHNOLOGY

L. Recipient/Contractor Point of Contact Contact for additional information (contact or organization name to be included in published citations and who would receive any external questions about the content of the STI Product or the research contained therein)

David Kershaw, Deputy Director

Name and/or Position

DKershaw@TRDA.ORG 321-269-6330

E-mail Phone

Technological Research and Development

Authority 


\section{PART II: STI PRODUCT MEDIA/FORMAT and LOCATION/TRANSMISSION}

(To be completed by Recipient/Contractor)

\section{A. Media/Format Information:}

1. MEDIUM OF STI PRODUCT IS:

$\square$ Electronic Document $\square$ Computer medium

$\square$ Audiovisual material X Paper $\square$ No full-text

2. SIZE OF STI PRODUCT 22 Pages

3. SPECIFY FILE FORMAT OF ELECTRONIC

DOCUMENT BEING TRANSMITTED, INDICATE:

$\square$ SGML $\square$ HTML $\square$ XML $\square$ PDF Normal $\square$ PDF Image

$\square$ WP-Indicate Version (5.0 or greater)

Platform/operating system

$\square$ MS-Indicate Version (5.0 or greater)

Platform/operating system

$\square$ Postscript

4. IF COMPUTER MEDIUM OR AUDIOVISUAL

a. Quantity/type (specify)

b. Machine compatibility (specify)

c. Other information about product format a user needs to know:

B. Transmission Information:

STI PRODUCT IS BEING TRANSMITTED:

$\square$ 1. Electronic via Elink

$X 2$. Via mail or shipment to address indicated

in award document (Paper products,

$C D-R O M$, diskettes, videocassettes, et.)

Final Report

$\square$ 2a. Information product file name

(of transmitted electronic format)

\section{PART III: STI PRODUCT REVIEW/RELEASE INFORMATION}

(To be completed by DOE)

A. STI Product Reporting Requirement Review:

$\square$ 1. THIS DELIVERABLE COMPLETES ALL REQUIRED DELIVERABLES FOR THIS AWARD

$\square$ 2. THIS DELIVERABLE FULFILLS A TECHNICAL REPORTING REQUIREMENT, BUT SHOULD NOT BE DISSEMINATED BEYOND DOE.

B. DOE Releasing Official

1. I VERIFY THAT ALL NECESSARY

REVIEWS HAVE BEEN COMPLETED AS

DESCRIBED IN DOE G 241.1-1A, PART II, SECTION 3.0 AND THAT THE STI PRODUCT SHOULD BE RELEASED IN ACCORDANCE WITH THE INTELLECTUAL PROPERTYIDISTRIBUTION LIMITATION ABOVE.

Released by (name)

Date

(mm/dd/yyyy)

E-mail

Phone 


\section{Form DOE F 241.3}

\section{STI Product Description}

Department of Energy Grant: DE-FG36-02GO12033

Project Name: National Alliance of Clean Energy Business Incubators

\section{Summary}

The National Alliance of Clean Energy Business Incubators, established in 2000 by the National Renewable Energy Laboratory (NREL), is an emerging network of select business incubators providing business and financial services to clean energy entrepreneurs. Aside from the Technological Research and Development Authority's (TRDA) Florida/NASA Business Incubation Center (FNBIC), nine other alliance partners serve clean energy business at the following locations:

- Alabama - BizTech and Business Innovation Center

- California - Environmental Business Cluster

- Georgia - The Advanced Technology Development Center (ATDC) at the Georgia Institute of Technology

- Massachusetts - The Boston Technology Venture Center

- New Mexico - Technology Ventures Corporation

- New York - The Rensselaer Polytechnic Institute Incubator with Albany NanoTech

- Texas - Austin Technology Incubator (ATI)

The Alliance incubators have the capability to provide a wide array of services that give their client companies a strong competitive advantage over other clean energy startups. Access to advice from leaders in the energy community, in-house consulting, strategy reviews, financing referrals, introductions to potential partners, and marketing and public relations aid are only a few of these services. The Alliance incubators are also able to provide client companies with appropriate rental space and flexible leases, shared office services and equipment, and the technology support services necessary for growth.

The Alliance was designed to provide focused business and financial assistance to clean energy companies with promising technologies, leading to an increase in the return on investment for the Department of Energy from its clean and renewable technology portfolio. By utilizing experienced personnel and proven business incubation strategies for building commercially successful companies, along with careful matching of incubator company commercialization activities with the realities of the marketplace, the grant effort in Florida was designed to lead to greater product penetration and growing market share for clean energy technologies. The source of funding for the project in Florida was a \$170,082.00 grant from the Department of Energy. 
During the grant period the business incubation program, was able to achieve significant results in a broad and challenging scope of work. The TRDA incubator began by marketing its services to 11 clean energy companies; providing direct business incubation services to seven new clean energy companies working in five different energy sectors: fuel cells, bio-power/biomass, bulk energy storage, hydrogen production, and wave power generation; assisted five of those companies in securing more than $\$ 400,000$ in new capital investment; supported the Alliance with advanced outreach materials to strengthen alliance member marketing and promotional efforts; increased its network of clean energy expertise by more than 45 professionals; and secured additional Department of Energy support for the Alliance in the fiscal year '04 federal budget of \$1 million.

The Florida/NASA Business Incubation Center is a program initiative of the Technological Research and Development Authority, a Florida Special District established by the Florida Legislature in 1987 to deliver the successful and cost-effective transfer of cutting-edge technologies to schools and businesses throughout the state. Through strategic alliances with NASA, the Department of Energy and other federal agencies, the aerospace industry and state partners-including the Department of Education, Enterprise Florida and the Department of Community Affairs/Florida Energy Office-TRDA and its programs are giving Floridians the edge to compete in the new millennium. 


\section{PROJECT TITLE}

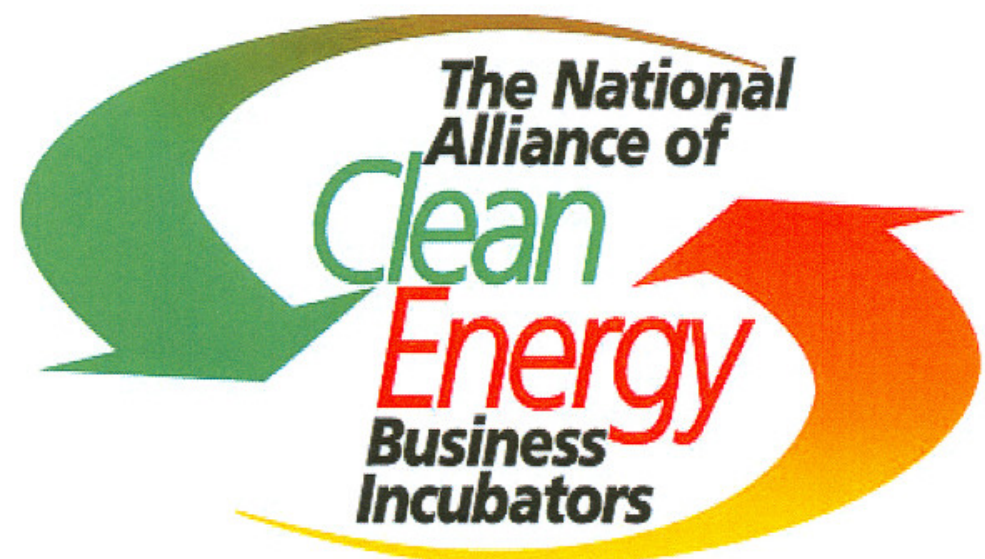

DOE Award Number: DE-FG36-02GO12033

\section{FINAL REPORT}

Reporting Period: $\underline{\text { Sept. 15, } 2002 \text { To Sept. 14, } 2003}$

Recipient Organization:

Technological Research and Development AuthorityFlorida/NASA Business Incubation Center

5195 South Washington Avenue

Titusville, FL 32780

Contact Information:

David Kershaw

Deputy Director

321-269-6330

$321-383-5260$

dkershaw@trda.org 

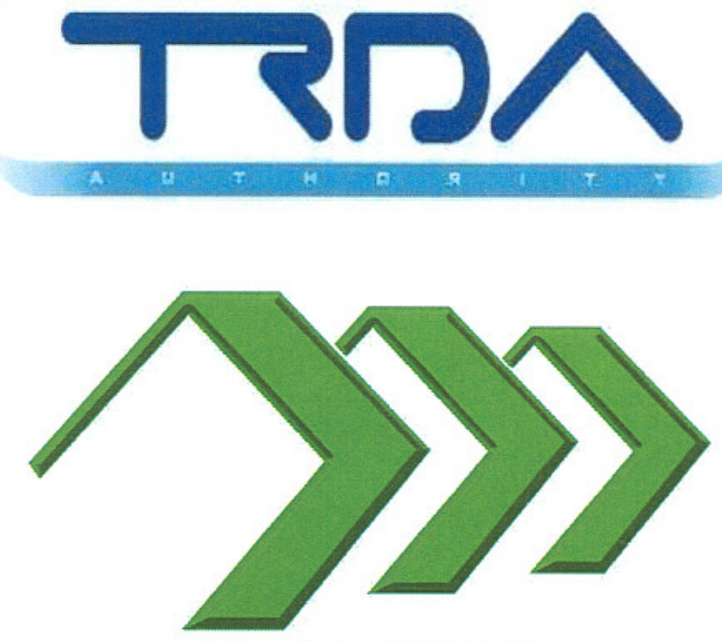

Florida/NASA

Business Incubation Center

\title{
FINAL SCIENTIFIC/ TECHNICAL REPORT
}

\author{
Department of Energy Award Number: DE-FG36-02GO12033
}

Date of Report: $\underline{12 / 11 / 03}$

Project Title: National Alliance of Clean Energy Incubators

Reporting Period: September 15, 2002 To September 14, 2003

\section{Executive Summary}

This document constitutes the Technological Research and Development Authority's (TRDA) Final Technical Report for The National Alliance of Clean Energy Business Incubators grant covering the period September 15, 2002 through September 14, 2003. The Department of Energy (DOE) Order 13332.2, "Uniform Reporting System for Federal Assistance" requires the TRDA to provide DOE with a Progress Report (Appendix 1), a Final Scientific/Technical Report including Form DOE F 241.3, a Financial Status Report (SF 269-Appendix 2), a Final Inventions and Patent Report and Property Certification (Appendix 3). This report contains those requirements as well as appendices of reference materials related to activities undertaken. 
The National Alliance of Clean Energy Business Incubators, established in 2000 by the National Renewable Energy Laboratory (NREL), is an emerging network of select business incubators providing business and financial services to clean energy entrepreneurs. Aside from the Florida/NASA Business Incubation Center (FNBIC), nine other alliance partners serve clean energy business at the following locations:

- Alabama - BizTech and Business Innovation Center

- California - Environmental Business Cluster

- Georgia - The Advanced Technology Development Center (ATDC) at the Georgia Institute of Technology

- Massachusetts - The Boston Technology Venture Center

- New Mexico -Technology Ventures Corporation

- New York - The Rensselaer Polytechnic Institute Incubator with Albany NanoTech

- Texas - Austin Technology Incubator (ATI)

The Alliance was designed to provide focused business and financial assistance to clean energy companies with promising technologies, leading to an increase in the return on investment for the Department of Energy from its clean and renewable technology portfolio. By utilizing experienced personnel and proven business incubation strategies for building commercially successful companies, along with careful matching of incubator company commercialization activities with the realities of the marketplace, the grant effort in Florida was designed to lead to a greater product penetration and growing market share for clean energy technologies. The source of funding for the project in Florida was a $\$ 170,082.00$ grant from the Department of Energy.

During the grant period the TRDA, together with its business incubation program, was able to achieve significant results in a broad and challenging scope of work. The TRDA incubator provided business incubation services to eight new clean energy companies working in five different energy sectors: fuel cells, bio-power/biomass, bulk energy storage, hydrogen production, and wave power generation; assisted five companies in securing more than $\$ 400,000$ in new capital investment; and supported the Alliance with advanced outreach materials to support alliance member marketing and promotional efforts.

The Technological Research and Development Authority's (TRDA) Florida/NASA Business Incubation Center (FNBIC) is pleased to present this final technical report for The National Alliance of Clean Energy Business Incubators grant. 


\section{Project Summary}

Before its receipt of the DOE Alliance grant, the TRDA had long developed and/or operated its own business incubation programs as well as managed energy technology investment programs for the State of Florida. The opportunity to merge these core competencies together into a unified effort through the Alliance initiative held great promise for clean energy companies. By availing themselves of the incubator's facilities and support programs, energy entrepreneurs were given the best possible chance to succeed and to gain competitive advantages over their clean energy rivals.

The specific objectives of the TRDA grant and the results of its efforts are discussed below. Appendix 4 of this report provides a summary of these activities.

\section{* Objective One}

Participate in at least one (1) NREL-sponsored Clean Energy Investor Forum.

\section{$>$ Result}

One forum was held during the grant period. As of member of the incubator alliance the TRDA participated in the National Renewable Energy Laboratory's $15^{\text {th }}$ Industry Growth Forum held in Albany, New York from October 29-30, 2002.

\section{Objective Two}

Market our incubation services directly to 10 Florida-based clean energy companies.

\section{$>$ Result}

Prior to the DOE grant the TRDA incubator had only one energy technology company participating in its business assistance program. Subsequent to the grant the incubator aggressively identified 11 promising clean energy companies and began marketing its services to them. At the close of the grant eight of the 11 companies had received services and/or financial support from the TRDA/Incubator.

- Kenaf USA (Biomass)-St. Augustine

- Materials Recycling Orlando (Biopower)-Orlando

- Sigarca, Inc. (Biopower)-Gainesville

- SRT Group (Hydrogen Production)_-Miami

- Dyneco, Inc. (PEM Fuel Cells)-Rockledge

- AquaMagnetics (Wave Power Generation)-Satellite Beach

- Apollo Energy, Inc. (Alkaline Fuel Cells)-Ft. Lauderdale

- MSS, Inc. (Tidal Power Generation)-West Palm Beach

- Electrodynamics, Inc. (Micro-turbines) -Orlando

- Clear Water Industries (Solar Photo Oxidation)_-Tampa

- TRL, Inc. (Bulk Energy Storage)-Daytona Beach 


\section{Objective Three}

Increase deal flow of clean energy companies resulting in five (5) new capital investments.

\section{Result}

While consulting with the TRDA and/or its incubator, six clean energy companies raised in excess of $\$ 400,000$ in new capital. These investments ranged in value from $\$ 30,000$ to $\$ 150,000$.

- Materials Recycling Orlando- $\$ 60,000$

- $\quad$ SRT Group- $\$ 30,000$

- Dyneco, Inc.- $\$ 150,000$

- Aquamagnetics- $\$ 30,000$

- Apollo Energy, Inc.- $\$ 150,000$

- MSS, Inc.- $\$ 30,000$

Total- $\$ 420,000$

\section{Objective Four}

Attend three (3) energy-related conferences.

\section{Result}

In addition to participating in the $15^{\text {th }}$ NREL Industry Growth Forum in Albany, New York during October of 2002, staff of the TRDA/Incubator attended two other energy focused conferences. These were the Southeast Regional Hydrogen Forum held at the Florida Solar Energy Center (FSEC) on April 29, 2003, the DOE Atlanta Regional Office Program Review July 14-16, 2003.

\section{Objective Five}

Increase Florida/NASA Business Incubation Center network of clean energy experts by five (5) individuals.

\section{Result}

To achieve this objective the TRDA incubator negotiated a Memorandum of Understanding with the Florida Solar Energy Center (FSEC). FSEC was formed to conduct renewable energy and energy efficiency research, training, testing and certification. Their research activities include solar electric and thermal systems, energy-efficient buildings, alternative transportation systems and fuels, hydrogen 
fuel, distributed generation and other energy-related areas. One of the responsibilities outlined in the MOU is that FSEC agrees to assist incubator clients by providing clean-energy technology evaluations, commercialization readiness evaluations, consulting and advisory services and business plan reviews. FSEC has more than 45 scientists, engineers and technicians on its staff available for consultation with the incubator and its clients.

\section{* Objective Six}

Refer four (4) presenting companies for clean energy investor forums.

\section{$>$ Result}

The TRDA incubator referred six of its affiliated companies to a regional and/or national investor forum. Two of these companies were invited to participate in the Industry Growth Forum.

- Kenaf USA-NREL Growth Forum

- Sigarca, Inc.-NREL Growth Forum

- Dyneco, Inc.-NREL Growth Forum

- Aquamagnetics-NREL Growth Forum

- TRL, Inc.-Florida Venture Forum

- SRT Group-NREL Growth Forum

The incubator also provided mentoring services to the Miami-based SRT Group in advance of their presentation at the $15^{\text {th }}$ Industry Growth Forum. SRT, which is commercializing an efficient flue gas desulphurization technology, provides electrical energy storage and produces hydrogen. In the weeks prior to the Forum, the incubator performed preliminary reviews and consultations on SRT's presentation via phone and email. Prior to the forum, the incubator conducted a "dry run" with SRT of their presentation before a panel of technology analysts and investors assembled by the incubator.

\section{* Objective Seven}

Enroll five (5) clean energy companies in the NREL online database.

\section{Result}

The incubator encouraged eight of its clean energy businesses to enroll. As of end of the grant period one company was formally registered in the database.

- Kenaf USA-registration pending

- Materials Recycling Orlando- registration pending

- Sigarca, Inc.- registration pending

- SRT Group-registration pending 
- Dyneco, Inc.- registration completed

- Aquamagnetics-registration pending

- Apollo Energy, Inc.- registration pending

- Electrodynamics, Inc.- registration pending

\section{* Objective Eight}

Distribute marketing materials at three (3) energy-related conferences and workshops.

\section{Result}

While participating in the $15^{\text {th }}$ Industry Growth Forum in October 2002, the April 2003 Southeast Regional Hydrogen Forum, and the July 2003 DOE Atlanta Regional Office Program Review, TRDA staff actively promoted the Alliance and its array of business and financial services to the energy community advocates.

\section{Objective Nine}

Provide business incubation services to five (5) clean energy companies, including, but not limited to:
a. Business Support Services
b. Access to Mentors
c. Access to Capital Resources/Investors
d. Network of Contacts
e. Access to a Service Provider Network
f. General Entrepreneurial Training

\section{$>$ Result}

In working with its affiliated companies the TRDA incubator was able to offer a broad range common support services including access to advisors, financial referrals, introductions to potential partners, on-site consulting, strategy reviews and public relations assistance. The support led to one incorporation (Kenaf, USA), the revision of a business plan and use of our service provider network (AquaMagnetics), strategy sessions, capital assistance and public relations (Sigarca and SRT Group), capital assistance (Apollo Energy, AquaMagnetics, Dyneco and SRT Group) and networking with potential strategic partners (TRL, Inc.).

Of particular note is the FNBIC incubator client Dyneco. As a result of having partnered with Parker-Hannifin's fuel cell business unit, Dyneco's activities have widened and now include product placement with some of Parker-Hannifin's fuel cell customers including Plug Power/GE, Giner, Electrochem, and Vectrex. Dyneco also continues to work with Ballard Power Systems on hydrogen circulators. Ballard successfully completed a 4,000-hour test of the Dyneco UniVane wet hydrogen 
circulator for their Mercedes bus chemical engines. Ballard is continuing the tests and has reported the promising results to Parker- Hannifin.

\section{Objective Ten}

Participate in each Clean Energy Alliance meeting.

\section{Result}

One meeting was held on February 21, 2003 at NREL in Golden Colorado. The purpose of this second meeting of the Alliance membership was to focus on fulfilling the responsibilities, managing the growth and effectively promoting the group's activities. The specific objectives of the meeting were to further establish and refine Alliance mission and metrics, to identify new strategies for empowering and supporting the Alliance, and to evaluate Alliance outreach activities. The meeting led to the issuance of an Alliance Metrics Survey in September of 2003 (Appendix 5). The TRDA developed the agenda for the February meeting (Appendix 6).

\section{* Objective Eleven}

Improve physical facilities to accommodate the needs of clean energy companies.

\section{Result}

The TRDA incubator completed the renovations of a new 3,000 SF facility in November of 2002. All of the incubator's on-site and affiliate clean energy companies are serviced from this facility.

\section{Objective Twelve}

Market the Alliance to a national constituency in order to create broad-based support for the Alliance concept, clean energy technologies and clean energy business development.

\section{$>$ Result}

To achieve its marketing results, the Alliance required credible collateral materials that communicated effectively. Pursuant to that need, the TRDA incubator completed the design and production of a set of trade show exhibit graphics for use at events such as the NREL Growth Forums and by the individual Alliance members for state and regional exhibitions. The graphics, which debuted at the 2002 Forum, featured high resolution images of clean energy technologies, text and an Alliance member locator map. The panels created a clean and vibrant marketing message to support face-to-face contact with potential clients, industry partners and investors. The exhibit 
was can scalable for use at smaller events and was made available to Alliance members upon request. During the reporting period the exhibit was requested and shipped three times to Alliance members. The graphic panels produced by the TRDA incubator can be seen in Appendix 7.

The incubator also prepared individualized, small-scale graphic systems for each Alliance member called "Rollups". These systems serve well as an informative visual asset for use with smaller regional marketing activities or within member incubator facilities. Each of the ten small "rollup" systems designed, incorporated images from the trade show exhibit and text specific to only the recipient member's program. When deployed, the systems measured $85 " \mathrm{~h} \times 33 \mathrm{k}$. w. By the close of the grant period seven of the systems had been delivered to Alliance members.

To accompany the graphic systems, the incubator also produced a three panel, fourcolor, brochure. The brochure, which introduced readers to the Alliance program and its objectives, was made first made available to attendees at the Albany Growth Forum in 2002. A second printing of the brochure was distributed to Alliance members after the $16^{\text {th }}$ Industry Growth Forum in Austin in November 2003. A copy of the latest printing is contained in Appendix 9.

The TRDA incubator also contracted with the Rensselaer Polytechnic Institute Incubator to design and develop a website for the Alliance program. The result can be viewed at www.cleanenergyalliance.com. The web site serves to promote the Alliance, provide a common identity for its members, and to channel resources to clean energy start-ups. The site also serves as an online clearinghouse for the Alliance support network, providing resources and access to networking partners.

Since this web site serves as the central pivot for the Alliance on the web, links to relevant information are included. The current links are:

- NREL Industry Growth Forum web site

- DOE/NREL web sites

- Individual member incubator web sites

- NREL Investor directory

- NREL Clean Energy Company directory

\section{Conclusions}

The vision of NREL to accelerate the growth of some of the best and the brightest young clean energy companies is being fulfilled by the National Alliance of Clean Energy Incubators initiative. The value proposition for DOE from this outreach effort toward business firms in the process of commercialization is clearly the technologies and the well-managed-incubated-companies behind them. We know that the majority of companies that the TRDA incubator supports, have historically had little or no contact with the federal energy agency. One could safely assume that the situation is similar with 
the businesses in the other nine Alliance incubators. These firms normally wouldn't be "doing business" with agency.

By its investment in the Alliance, which creates an umbilical cord into leading business incubators, NREL connects with companies with a low probability of failurecompanies that are positioned for success. This represents a significant departure from the way government traditionally has conducted the innovation and commercialization process, i.e. cloaked in secrecy and not mindful of the commercial marketplace. Through the TRDA incubator alone, DOE has helped make supportive investments in eight "promising" clean energy companies with equally promising technologies.

There are clear benefits to NREL/DOE in having its "fingers" in a number of Alliance tested, technology pies. This is especially true if the U.S. were to experience an energy-related, Sept. 11 type event. With the Alliance network in place, the scouring for technology solutions to handle another energy crisis becomes a much simpler process. A majority of the Alliance incubator clients have technologies with the potential to significantly reduce our nation's reliance on foreign oil as well as increase national security. An important benefit also accrues to the Alliance's clean energy clients from the relationship. Their successful innovations earn a tacit "seal of approval" from the Alliance/DOE association. This can often accelerate commercial success.

In the first year of a technology/business development program such as the National Alliance of Clean Energy Business Incubators, it is unrealistic to expect disruptive or stunning change to occur, but the TRDA incubator has achieved significant early progress with the development of the clean energy sector in Florida. Its eight client companies employ 24 people and have raised more than $\$ 400,000$ in investment capital; two companies have participated in the NREL Industry Growth Forums. A third company is poised for high growth after licensing their air compressor and hydrogen circulator technologies to Parker-Hannefin, a supplier to Plug Power and other key fuel cell suppliers. The incubator itself has leveraged more than \$2 million in state and other federal funding since the DOE grant of $\$ 170,083$.

Looking back over this grant period, we are pleased with the progress already made and excited about the promise the Alliance initiative continues to offer. For any additional information pertaining to this grant, please contact David Kershaw at 321-2696330 . 


\section{PROGRESS REPORT}

Department of Energy Grant: DE_FG36-02GO12033

Date of Report: $\underline{12 / 12 / 03}$

Project Name: National Alliance of Clean Energy Incubators

Reporting Period: September 15, 2002 To April 30, 2003

\section{Introduction}

The Technological Research and Development Authority's (TRDA) Florida/NASA Business Incubation Center (FNBIC) is pleased to present this second progress report for the National Alliance of Clean Energy Business Incubators grant. This report covers the period beginning September 15, 2002 through April 30, 2003. Pursuant to Department of Energy reporting checklist requirements, this report summarizes the work performed and results achieved during the reporting period.

\section{The Program}

The National Alliance of Clean Energy Business Incubators is an emerging network of select business incubators providing business and financial services to clean energy entrepreneurs. Aside from the Florida/NASA Business Incubation Center (FNBIC) operated by the TRDA, nine other alliance partners in Alabama, California, Georgia, Massachusetts, New York, and Texas serve clean energy businesses under this program.

By offering affordable space and shared office equipment and services, the incubator makes it possible to reduce many of the costs associated with establishing and operating a small business. Support facilities and programs help train and nurture the new entrepreneurs in the establishment and operation of their technology-based companies, thereby giving them the best possible chance to succeed. 


\section{Objectives}

As a part of its grant agreement with the Department of Energy, the Florida/ NASA Business Incubation Center is participating in supporting the goals of the Alliance through the accomplishment of the following objectives:

1. Participate in at least one (1) NREL-sponsored Clean Energy Investor Forum

2. Market our incubation services directly to 10 Florida-based clean energy companies

3. Increase deal flow of clean energy companies resulting in five (5) new capital investments

4. Attend three (3) energy-related conferences

5. Increase Florida/NASA Business Incubation Center network of clean energy experts by five (5) individuals

6. Refer four (4) presenting companies for clean energy investor forums

7. Enroll five (5) clean energy companies in the NREL online database

8. Distribute marketing materials at three (3) energy related conferences and workshops

9. Provide business incubation services to five (5) clean energy companies, including, but not limited to:

a. Business Support Services

b. Access to Mentors

c. Access to Capital Resources/Investors

d. Network of contacts

e. Access to a Service Provider Network

f. General Entrepreneurial Training

10. Participate in each Clean Energy Alliance meeting

11. Improve physical facilities to accommodate the needs of clean energy companies

12. Market the Alliance to a national constituency in order to create broad-based support for the Alliance concept, clean energy technologies and clean energy business development. 


\section{Results}

By the end of the interim reporting period on April 30, 2003, FNBIC had made steady progress on most of its objectives. The following chart details the progress.

\begin{tabular}{|c|c|c|}
\hline Objectives & $\begin{array}{c}\text { Quantitative } \\
\text { Target }\end{array}$ & $\begin{array}{c}\text { Accomplished } \\
\text { To Date-4/30/03 } \\
\end{array}$ \\
\hline $\begin{array}{l}\text { Participate in at least one NREL } \\
\text { Clean Energy Investment Forum }\end{array}$ & 1 & 1 \\
\hline $\begin{array}{l}\text { Market FNBIC services directly to } \\
\text { Ten Florida-based clean energy } \\
\text { companies }\end{array}$ & 10 & 7 \\
\hline $\begin{array}{l}\text { Increase deal flow of client companies } \\
\text { resulting in five new } \\
\text { capital investments }\end{array}$ & 5 & 4 \\
\hline $\begin{array}{l}\text { Attend three energy-related } \\
\text { conferences }\end{array}$ & 3 & 1 \\
\hline $\begin{array}{l}\text { Increase network of clean energy experts } \\
\text { by five individuals }\end{array}$ & 5 & 1 \\
\hline $\begin{array}{l}\text { Refer four presenting companies to } \\
\text { energy investor forums }\end{array}$ & 4 & 0 \\
\hline $\begin{array}{l}\text { Enroll five clean energy companies in the } \\
\text { NREL online database }\end{array}$ & 5 & 0 \\
\hline $\begin{array}{l}\text { Distribute marketing materials at } \\
\text { Three energy-related conferences }\end{array}$ & 3 & 1 \\
\hline $\begin{array}{l}\text { Provide business incubation services to } \\
\text { five energy companies }\end{array}$ & 5 & 2 \\
\hline $\begin{array}{l}\text { Participate in each Clean Energy } \\
\text { Alliance meeting }\end{array}$ & 1 & 1 \\
\hline $\begin{array}{l}\text { Market the Alliance nationally } \\
\text { To create broad-based support }\end{array}$ & 1 & $\begin{array}{l}\text { See Discussion } \\
\text { Below }\end{array}$ \\
\hline Improve FNBIC physical facilities & 1 & $\begin{array}{c}\text { Renovations } \\
\text { Completed } 11 / 02\end{array}$ \\
\hline
\end{tabular}




\section{Market the Alliance Nationally}

As discussed in the previous interim report, FNBIC completed the design and production of a set of trade show exhibit graphics. The graphics, which debuted at the 2002 Industry Growth Forum, featured high resolution images of clean energy technologies, text and an Alliance member locator map on a lightweight 10'x10' exhibit structure. The panels created a clean and vibrant marketing message to support face-toface contact with potential clients, industry partners and investors. The exhibit was scalable for use at smaller events and was made available to Alliance members upon request.

FNBIC has made further progress on preparing a small-scale graphic system individualized for Alliance members that can be used in regional marketing activities or within member incubator facilities. The small "rollup" systems incorporated images from the trade show exhibit and text specific to only the recipient member's program. When deployed the systems will be 85 "h $\mathrm{x} 33$ "w. The FNBIC now expects the first of these systems to be delivered to Alliance members during the third quarter of 2003.

As a companion piece to the graphic systems FNBIC produced a three panel, four-color, brochure. The brochure introduces readers to the Alliance program and its objectives and was made available to attendees at the Albany Growth Forum. Each member of the Alliance has received one hundred copies for their regional marketing initiatives. FNBIC is planning a reprint of these brochures for distribution in the fourth quarter of 2003.

\section{Conclusion}

As a member of the Alliance, the Florida/NASA Business Incubation Center is working to strengthen the Alliance and welcome new energy companies, venture firms, angel investors, nonprofits, government organizations, and other committed to supporting the clean energy industry. During this reporting period we are pleased with the steady progress made and look forward to accomplishing the remaining objectives set forth in our grant agreement. Please Contact David Kershaw at 321-267-5956 for any additional information pertaining to this grant. 


\section{FINANCIAL STATUS REPORT}

(Long Form)

(Follow instructions on the back)

\begin{tabular}{|c|c|c|c|c|}
\hline $\begin{array}{l}\text { 1. Federal Agency and Organizational Element } \\
\text { to Which Report is Submitted } \\
\text { Dept. Energy GFO }\end{array}$ & $\begin{array}{l}\text { 2. Federal Grant or Other Identifying Number Assigned } \\
\text { By Federal Agency } \\
\text { DE-FG36-02 GO } 12033\end{array}$ & $\begin{array}{l}\text { OMB Approval } \\
\text { No. 0348-0039 }\end{array}$ & $\begin{array}{l}\text { Page } \\
1\end{array}$ & $\begin{array}{l}\text { of } \\
1 \\
\text { pages }\end{array}$ \\
\hline
\end{tabular}

3. Recipient Organization (Name and complete address, including ZIP code)

Technological Research and Development Authority

5195 South Washington Avenue, Titusville, FL 32780

\begin{tabular}{|c|c|c|c|c|}
\hline $\begin{array}{l}\text { 4. Employer Identification Number } \\
\text { 59-2908388 }\end{array}$ & \multicolumn{2}{|c|}{$\begin{array}{l}\text { 5. Recipient Account Number or Identifying Number } \\
\text { DUNS: } 028404700\end{array}$} & $\begin{array}{l}\text { 6. Final Report } \\
\Xi \text { Yes } \square \text { No }\end{array}$ & 7. Basis \\
\hline $\begin{array}{l}\text { 8. Funding/Grant Period (See instructions) } \\
\text { From: (Month, Day, Year) } \\
\mathbf{9 / 1 5 / 0 2}\end{array}$ & $\begin{array}{l}\text { To: (Month, Day, Year) } \\
9 / 14 / 03\end{array}$ & \multicolumn{2}{|c|}{$\begin{array}{l}\text { 9. Period Covered by this Report } \\
\text { From: (Month, Day, Year) } \\
\mathbf{9 / 1 5 / 0 2}\end{array}$} & $\begin{array}{l}\text { To: (Month, Day, Year) } \\
9 / 14 / 03\end{array}$ \\
\hline \multicolumn{2}{|l|}{ 10. Transactions: } & $\begin{array}{c}\text { I } \\
\text { Previously Reported } \\
\end{array}$ & $\begin{array}{c}\text { II } \\
\text { This Period } \\
\end{array}$ & \begin{tabular}{|l} 
III \\
Cumulative \\
\end{tabular} \\
\hline a. Total outlays & & $18,892.06$ & $56,079.26$ & $74,971.32$ \\
\hline b. Refunds, rebates, etc. & & 0.00 & 0.00 & 0.00 \\
\hline \multicolumn{2}{|c|}{ c. Program income used in accordance with the deduction alternative } & 0.00 & 0.00 & 0.00 \\
\hline \multicolumn{2}{|c|}{ d. Net outlays (Line $a$, less the sum of lines $b$ and $c$ ) } & $18,892.06$ & $56,079.26$ & $74,971.32$ \\
\hline \multicolumn{2}{|l|}{$\begin{array}{l}\text { Recipient's share of net outlays, consisting of: } \\
\text { e. Third party (in-kind) contributions }\end{array}$} & 0.00 & 0.00 & 0.00 \\
\hline \multicolumn{2}{|c|}{ f. Other Federal awards authorized to be used to match this award } & 0.00 & 0.00 & 0.00 \\
\hline \multicolumn{2}{|c|}{$\begin{array}{l}\text { g. Program income used in accordance with the matching or cost } \\
\text { sharing alternative }\end{array}$} & 0.00 & 0.00 & 0.00 \\
\hline \multicolumn{2}{|c|}{ h. All other recipient outlays not shown on lines e, f or $g$} & 0.00 & 0.00 & 0.00 \\
\hline \multicolumn{2}{|c|}{ i. Total recipient share of net outlays (Sum of lines, $e, f, g$ and $h$ ) } & 0.00 & 0.00 & 0.00 \\
\hline \multicolumn{2}{|c|}{ j. Federal share of net outlays (line $d$ less line i) } & $18,892.06$ & $56,079.26$ & $74,971.32$ \\
\hline \multicolumn{2}{|l|}{ k. Total unliquidated obligations } & & & 0.00 \\
\hline \multicolumn{2}{|c|}{ 1. Recipient's share of unliquidated obligations } & & & 0.00 \\
\hline \multicolumn{2}{|l|}{ m. Federal share of unliquidated obligations } & & & 0.00 \\
\hline \multicolumn{2}{|c|}{ n. Total federal share (sum of lines $j$ and $m$ ) } & & & $74,971.32$ \\
\hline \multicolumn{2}{|c|}{ o. Total federal funds authorized for this funding period } & & & $170,(082.00$ \\
\hline \multicolumn{2}{|c|}{ p. Unobligated balance of federal funds (Line o minus line $n$ ) } & & & $95,110.68$ \\
\hline
\end{tabular}

\begin{tabular}{|c|c|c|c|c|c|}
\hline \multicolumn{3}{|c|}{$\begin{array}{l}\text { Program income, consisting of: } \\
\text { q. Disbursed program income shown on lines c and/or } \mathrm{g} \text { above }\end{array}$} & & & 0.00 \\
\hline \multicolumn{3}{|c|}{ r. Disbursed program income using the addition alternative } & & & 0.00 \\
\hline \multicolumn{3}{|c|}{ s. Undisbursed program income } & & & 0.00 \\
\hline \multicolumn{3}{|c|}{ t. Total program income realized (Sum of lines $q, r$ and $s$ ) } & & & 0.00 \\
\hline \multirow{3}{*}{$\begin{array}{l}\text { 11. Indirect } \\
\text { Expense }\end{array}$} & \multicolumn{5}{|c|}{ a. Type of Rate (Place " $X^{\prime \prime}$ in appropriate box) } \\
\hline & $\begin{array}{r}\text { n_Rnevisional } \\
\end{array}$ & Predetermined & \multicolumn{2}{|c|}{ Fixed } & \\
\hline & $11.26 \%$ & $\begin{array}{ll}\text { c. Base } & 67,383.89 \\
\end{array}$ & $\begin{array}{r}\text { d. Total Amount } \\
7,587.43\end{array}$ & $\begin{array}{l}\text { e. Federal Share } \\
\qquad 7,587.43\end{array}$ & \\
\hline
\end{tabular}

12. Remarks: Attach any explanations deemed necessary or information required by Federal sponsoring agency in compliance with

governing legislation:

We have included the applied indirect costs of $\$ 7,587.43$ in the total outlay amount noted in line $10 \mathrm{a}$.

13. Certification: I certify to the best of my knowledge and belief that this report is correct and complete and that all outlays and unliquidated obligations are for the purpose set forth in the award documents.

Typed or Printed Name and Title

David Kershaw. Deputy Director

Signature of Authorized Certifying Officia

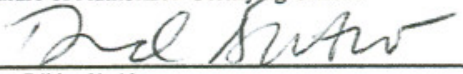

Previous Edition Usable

NSN 7540-01-012-4285
$269-104$

Telephone (Area code, number and extension)

321-269-6330 $\times 243$

Date Report Submitted

December 10.2003

Standard Form 269 (RI:V 2-92)

Prescribed by $($ MB Circulars $\mathrm{A}-102$ and $\mathrm{A}-110$ 


\section{FINAL INVENTIONS AND PATENT AND PROPERTY CERTIFICATION REPORTS}

\section{FINAL INVENTIONS AND PATENT REPORT}

No subject inventions or patents are required to be disclosed pursuant to this grant.

\section{PROPERTY CERTIFICATION}

One general purpose equipment item was acquired with the grant funds. This item was a Dell Computer workstation purchased at a cost of $\$ 1,060.00$. 


\section{SCOPE OF WORK SUMMARY RESULTS}

\begin{tabular}{|c|c|c|}
\hline Objectives & $\begin{array}{c}\text { Quantitative } \\
\text { Target }\end{array}$ & $\begin{array}{c}\text { Accomplished } \\
\text { To Date-9/14/03 }\end{array}$ \\
\hline $\begin{array}{l}\text { Participate in at least one NREL } \\
\text { clean energy Investment Forum }\end{array}$ & 1 & 1 \\
\hline $\begin{array}{l}\text { Market FNBIC services directly to } \\
\text { ten Florida-based clean energy } \\
\text { companies }\end{array}$ & 10 & 11 \\
\hline $\begin{array}{l}\text { Increase deal flow of client companies } \\
\text { resulting in five new } \\
\text { capital investments }\end{array}$ & 5 & 6 \\
\hline $\begin{array}{l}\text { Attend three energy-related } \\
\text { conferences }\end{array}$ & 3 & 3 \\
\hline $\begin{array}{l}\text { Increase network of clean energy experts } \\
\text { by five individuals }\end{array}$ & 5 & $45+$ \\
\hline $\begin{array}{l}\text { Refer four presenting companies to } \\
\text { energy investor forums }\end{array}$ & 4 & 6 \\
\hline $\begin{array}{l}\text { Enroll five clean energy companies in the } \\
\text { NREL online database }\end{array}$ & 5 & 1 \\
\hline $\begin{array}{l}\text { Distribute marketing materials at } \\
\text { three energy-related conferences }\end{array}$ & 3 & 3 \\
\hline $\begin{array}{l}\text { Provide business incubation services to } \\
\text { five clean energy companies }\end{array}$ & 5 & 7 \\
\hline $\begin{array}{l}\text { Participate in each Clean Energy } \\
\text { Alliance meeting }\end{array}$ & 1 & 1 \\
\hline $\begin{array}{l}\text { Market the Alliance nationally } \\
\text { to create broad-based support }\end{array}$ & 1 & $\begin{array}{l}\text { See Discussion } \\
\text { Below }\end{array}$ \\
\hline Improve FNBIC physical facilities & 1 & $\begin{array}{c}\text { Renovations } \\
\text { Completed } 11 / 02\end{array}$ \\
\hline
\end{tabular}




\section{National Alliance of Clean Energy Business Incubators Survey Status}

\begin{tabular}{|c|c|c|c|c|c|c|}
\hline Survey as of June, 2003 & Current & Graduate & Intrapreneur & Total & Average & Median \\
\hline \# of clean energy members & 85 & 3 & 5 & 93 & 9 & 8 \\
\hline \# of employees at clean energy firms & 999 & 6 & 550 & 1,555 & 155 & 50 \\
\hline Capital raised for clean energy companies & $\$ 24,270,000$ & $\$$ & $\$ \quad 5,000,000$ & $\$ 29,270,000$ & $\$ 2,927,000$ & $\$ 1,500,000$ \\
\hline Annual revenue generated by clean energy companies & $\$ 85,575,600$ & $\$ \quad 1,000,000$ & $\$ 720,000,000$ & $\$ 806,575,600$ & $\$ 80,657,560$ & $\$ 825,000$ \\
\hline State money leveraged & & & & $\$ 5,295,000$ & $\$ 529,500$ & $\$ 42,500$ \\
\hline Other leveraged funds & & & & $\$ 6,141,000$ & $\$ 614,100$ & $\$ 70,500$ \\
\hline Partnerships & & & & 11 & 1 & 1 \\
\hline Technologies commercialized & & & & 2 & 0 & 0 \\
\hline Awards & & & & 17 & 2 & 0 \\
\hline
\end{tabular}




\section{The National Alliance of Clean Energy Business Incubators \\ Strategy Session \\ February 21, 2003}

\section{Agenda}

Meeting Purpose: To focus on fulfilling the responsibilities, managing the growth and effectively promoting the activities of the Alliance.

Objectives: 1) Further establish and refine Alliance Mission and Metrics, 2) Identify new strategies for empowering and supporting the Alliance, and 3) Evaluate Alliance outreach activities.

7:30 Continental Breakfast

8:15 Welcome and NREL Update NREL Management

8:45 Introductions and Updates All

9:30 Reporting

- Contract Compliance

- Review of Progress on Contract Metrics

- DOE Visit and Follow-Up

- Annual Report

Dave Kershaw, Jim Spaeth \& Steve Scott

All

Richard Amato

Frank Kinney

10:15 Break

$10: 30$

Mission and Evaluation Metrics

Richard Amato

$11: 30$

Integration with State Initiatives (CATX)

Jim Robbins \& Richard Amato

$12: 00$

Lunch \& Round Table Discussion

NREL Management

1:15 Marketing Program

- Website

- NREL Growth Link/Incubator.com

- Brochures/Roll-Up

- Press Coverage

Simon Balint

Simon Balint \& Marty Murphy

Dave Kershaw

All

2:00 Forum Analysis

- $15^{\text {th }}$ Industry Growth Forum-Albany Michael Fancher $16^{\text {th }}$ Industry Growth Forum-TBD

Richard Amato \& Marty Murphy

3:00 Break

3:15 Legislative Priorities

- FY 03 Process Review

- FY 04 Priorities \& Planning

- Other

Frank Kinney \& Eddy Pauley

Frank Kinney \& Eddy Pauley

All

4:00 Alliance Membership Expansion

All

- Process/Admission Schedule

- Possible Candidates

4:30 Self Governance

- Next Year's Chairs

- Transitioning to Future Leadership

Frank Kinney

Richard Amato

Wrap-up-Next Steps \& Action Items

Chris Downing 

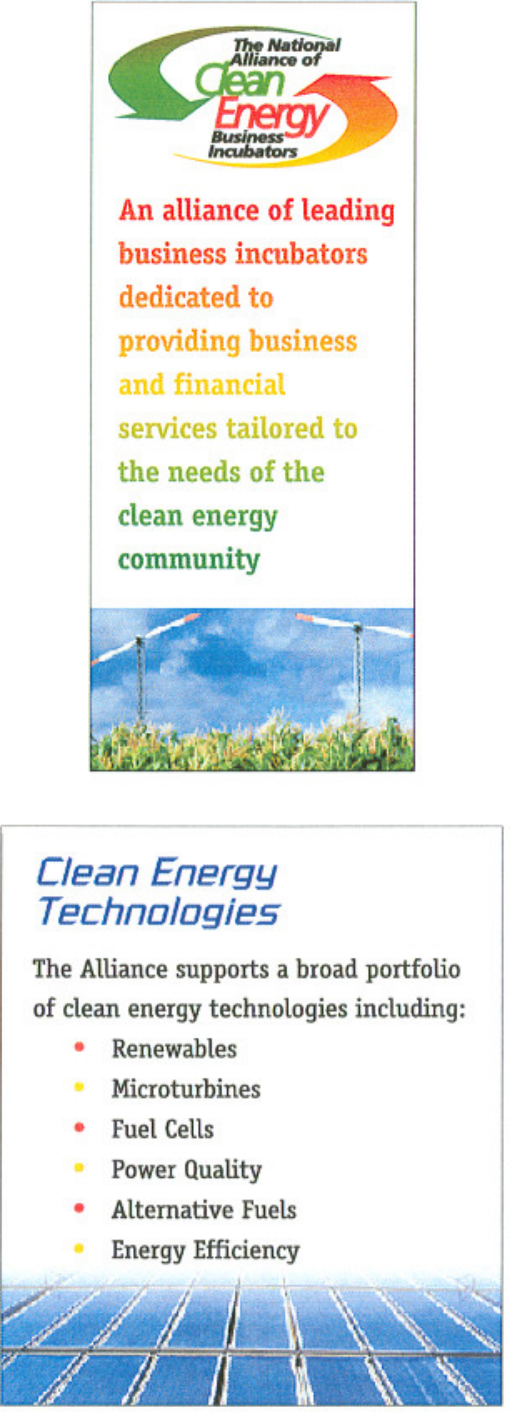

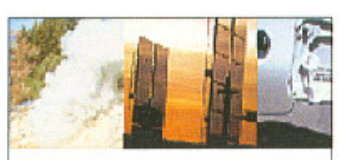

The Alliance

Our Alliance incubators

accelerate the growth

and success of

entrepreneurial

companies through an

array of business

support resources:

- Access to venture capital investment

- Business mentoring

- Facilitation of strategic alliances

- Marketing and public relations

- Technology support services

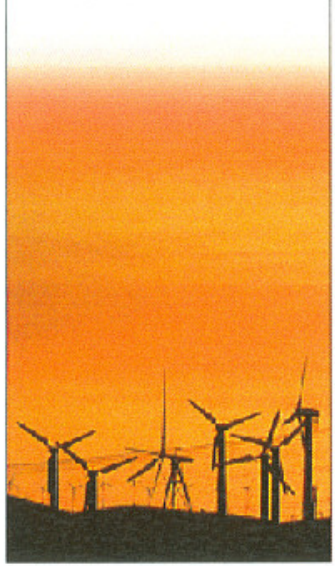

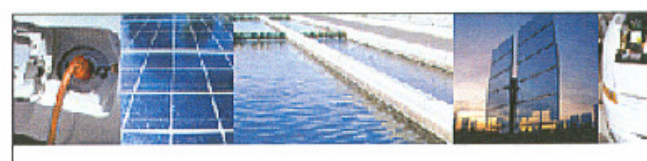

The Alliance of Clean Energy Business Incubators

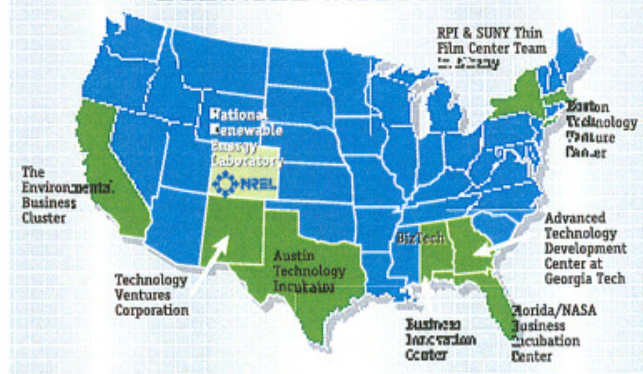

The Alliance offers more than $350,000 \mathrm{SF}$ of incubation space and has leveraged $\$ 9.2 \mathrm{M}$ in state and local support. Private sector support to members and client companies exceeds $\$ 383 \mathrm{M}$.

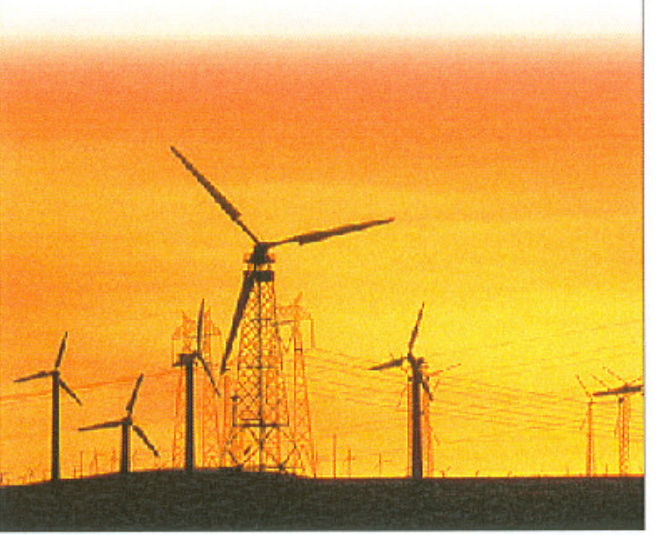

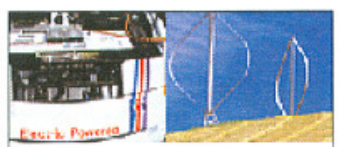

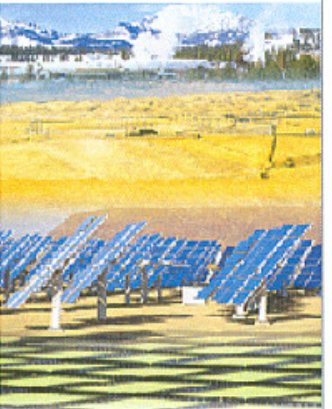

The Alliance is a

National Renewable Energy Laboratory initiative with support from the US Depart-

ment of Energy.

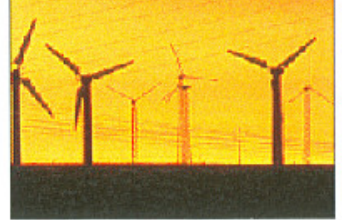




\section{The Dpportunity}

ane deregulation and restructuring of the electric utility industry, coupled with growing environmental concerns, create unparalleled opportunities for new clean energy products, services and technologies. Power providers, venture capital firms and public dollars are being invested in emerging energy companies at an unprecedented rate.

To take full advantage of these opportunities, companies must prepare themselves for success. Alliance incubators help clean energy companies grow strong and provide business assistance services that allow them to develop competitive advantages over other clean energy start-ups.

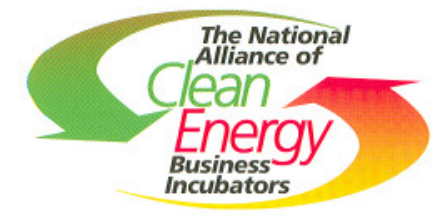

The Alliance is a National Renewable Energy Laboratory (NREL) initiative with support from the US Department of Energy.

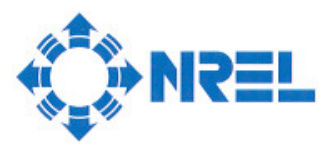

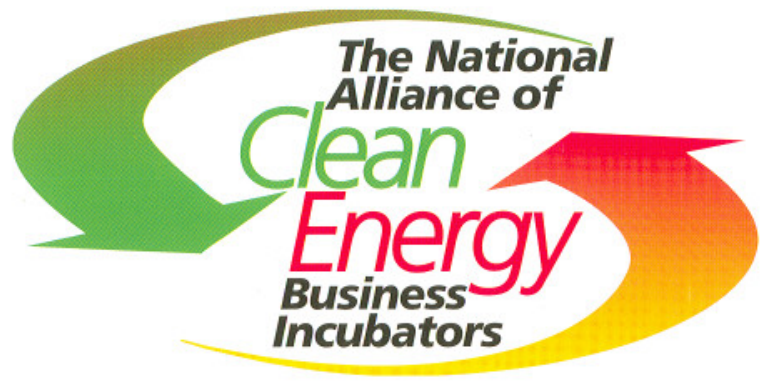

An Alliance of leading business incubators dedicated to providing business and financial services tailored to the needs of the clean energy cammunity.

www.cleanenergyalliance.com 


\section{$1+2=2-1=$}

\section{The Alliance}

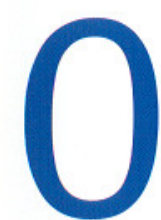

ur Alliance incubators accelerate the growth and success of entrepreneurial companies through an array of business support resources.

Access to venture capital investment

- Business Mentoring from Energy experts and business leaders

Facilitation of strategic alliances

. Marketing and public relations

Technology support services

The Alliance offers more than 350,000 SF of incubation space in nine states. Alliance incubators have leveraged more than $\$ 11 \mathrm{M}$ in state and local support and helped client companies raise more than $\$ 24 \mathrm{M}$ in capital investment. Annual revenue generated by Alliance energy companies exceeds $\$ 85 \mathrm{M}$.
Cander

The Alliance of Clean Energy Business Incubators

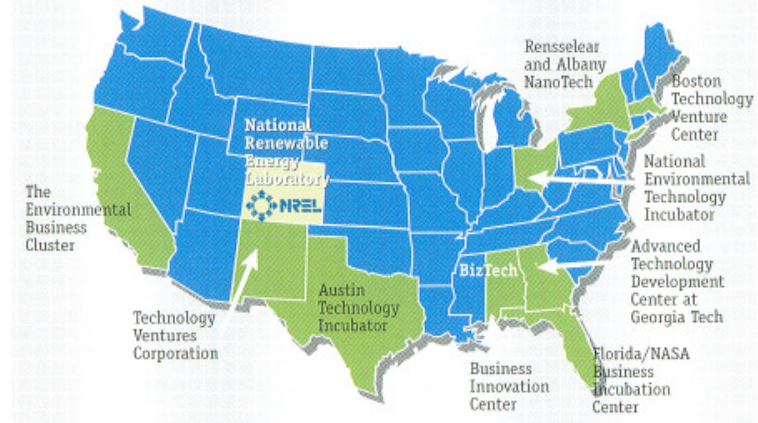

\section{Capital Investment} Qpportunities

Entrepreneurs and network participants benefit from regular exposure to capital investment opportunities including:

Industry Growth Forums: National Renewable Energy Laboratory's venture-style investment forums

Regional Investment and Networking Forums: Hosted by member incubators across the country

\section{Clean Energy Technologies}

The Alliance supports a broad portfolio of clean energy technologies including:

renewables

Microturbines

. Fuel cells

. Power Quality

Energy efficiency

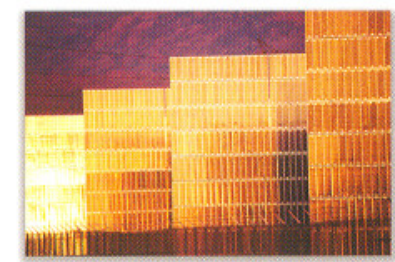

Alternative fuels

Energy-related e-commerce and information technologies

- Hydro-electric

- Transportation

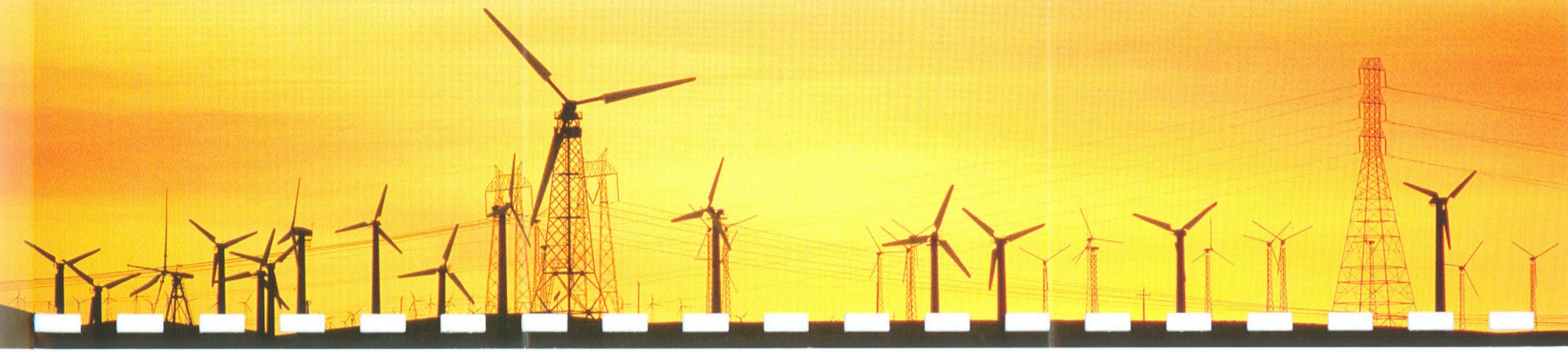

